\title{
Application of Caulerpa racemosa extract as a natural colourant in raw noodles
}

\author{
Sholicha, F., "Dewi, E.N. and Purnamayati, L. \\ Department of Fish Product Technology, Faculty of Fisheries and Marine Science, Diponegoro University, \\ Jl. Prof. H. Soedarto, SH, Tembalang, Semarang, Central Java 50275, Indonesia.
}

\author{
Article history: \\ Received: 9 February 2021 \\ Received in revised form: 24 \\ March 2021 \\ Accepted: 27 March 2021 \\ Available Online: 28 July \\ 2021
}

\section{Keywords:}

Caulerpa racemosa,

Macroalgae,

Natural colourant,

Quality,

Raw noodles

DOI:

https://doi.org/10.26656/fr.2017.5(S3).009

\begin{abstract}
Caulerpa racemosa is a green macroalga that contains chlorophyll, a natural colorant, which has anti-inflammatory, antibacterial, antiparasitic, and antioxidant properties. This study aimed to determine the effect different concentrations of $C$. racemosa mixed with distilled water have on raw noodles and to discover the optimal concentration. Fresh $C$. racemosa was mixed with distilled water into $25 \%, 50 \%$, and $75 \% \mathrm{w} / \mathrm{v}$ solutions. It was then added to the dough for making noodles, the latter of which were tested in triplicate for colour, total phenol, total chlorophyll, protein, tensile strength, and consumer preference. The $C$. racemosa extracts had a significant effect $(\mathrm{P}<0.05)$ on colour, total phenol, total chlorophyll, protein, and consumer preference, but did not significantly influence tensile strength. Noodles with a $75 \%$ C. racemosa concentration were preferred for their attractive green colour.
\end{abstract}

\section{Introduction}

Colour plays an important role in a consumer's preference for a product. The application of synthetic dyes tends to increase because it is cheaper, produces more attractive colour, and is more stable than natural ones (Saleem et al., 2013). Fast Green FCF is a green synthetic dye. Continuous use or exceeding the standard (maximum $100 \mathrm{mg} / \mathrm{kg}$ ) may be harmful to health (FAO, 2017). Synthetic colours are difficult for our intestines to absorb, have tumorigenic properties, and mutagenic effects in experimental animals and humans. It also irritates the eyes, skin, digestive tract, and respiratory tract (Okafor et al., 2016; Sadar et al., 2017). We have seen a shift back to sustainable and renewable natural products. One natural dye that can replace synthetic dyes comes from Caulerpa racemosa.

Caulerpa is a green algae group that includes feather seaweed (an edible macroalga) and contains bioactive substances (Tapotubun et al., 2020). According to Merdekawati and Susanto (2009), green algae contain chlorophyll-a (26.82\%), chlorophyll-b (12.91\%), and are effective as an antioxidant. Caulerpa racemosa, also known as sea grape, is a grape-shaped green alga found widespread in Indonesian waters. Caulerpa racemosa in Indonesia still sees limited use, mostly in fresh vegetables or mixed with fruit.
Noodles are popular foods in Asia and are made from wheat flour into a long and thin shape. It is a staple Asian food that can be categorized as a substitute food because it acts as an alternative to rice, is affordable, and is easy to serve (Sikander et al., 2017; Adejuwon et al., 2019). Noodles are usually yellow but may come in a variety of colours to attract customers. Vegetables may be added to noodles to provide natural colouring and to make them healthier, such as noodles with spinach puree (Shere et al., 2018), carrot and tomato (Yadav et al., 2014), or celery (Minarovičová et al., 2018). Frequent consumption of instant noodles remains unhealthy, making further innovation in healthier noodles is needed. This study aimed to determine the effect of various $C$. racemosa concentrations on the colour, total phenol, total chlorophyll, protein, and consumer preference for noodles.

\section{Materials and methods}

\subsection{Materials}

Fresh C. racemosa was obtained from the Centre of Brackish Water Research, Jepara, Indonesia. Distilled water was obtained from a chemical supplier in Semarang, Central Java, Indonesia. Wheat flour and eggs were bought from a local market in Semarang. 


\subsection{Noodle preparation}

Caulerpa racemosa was extracted by Oktiarni et al. (2012) in $25 \%, 50 \%$, and $75 \%(\mathrm{w} / \mathrm{v})$ solutions. The mixtures were then blended until homogenous, filtered, and mixed with the noodle dough. The preparation of raw noodles was referred to Koswara (2009) by mixing wheat flour $50 \%$, eggs $5 \%$, and the $C$. racemosa extracts $45 \%$ and then stirred until homogenous. The dough was left for 10 mins, then pressed with a roll press, stretched until it formed a thin dough sheet $(1 \mathrm{~mm})$, and cut into string-shapes (1.0-1.5 mm thick, $50 \mathrm{~cm}$ long).

\subsection{Colour assay $(L, a, b)$}

The colour assay was done with a Chroma Meter (Konica Minolta CR-410) connected to an electric current (Hruškqvá et al., 2011). The measuring head was held horizontally over each sample, and measurements were made when the indicator light was on. Measurements for $\mathrm{L}, \mathrm{a}^{*}$, and $\mathrm{b}^{*}$ were taken three times and the values were noted from the Chroma Meter display each time.

\subsection{Total phenol}

The total phenol was measured using the method adapted from Priyadarisani et al. (2014). Approximately $5 \mathrm{~g}$ of noodles were dissolved in $100 \mathrm{~mL}$ of distilled water, the resulting homogenous solution was filtered, and $1 \mathrm{~mL}$ of the filtrate was taken and added to $0.5 \mathrm{~mL}$ of Folin-Ciocalteu reagent and $1 \mathrm{~mL}$ of saturated $\mathrm{Na}_{2} \mathrm{CO}_{3}$ solution, and left for 10 mins. Finally, the solution was added with up to $10 \mathrm{~mL}$ distilled water. The absorbance was measured with a spectrophotometer (Shimadzu, Japan) at $730 \mathrm{~nm}$. The total phenol was then calculated with a phenol standard curve.

\subsection{Total chlorophyll}

A total chlorophyll assay was performed based on Hendriyani and Setiari (2009) for extracted solvents reference. A $5 \mathrm{~g}$ sample was extracted with $100 \mathrm{~mL}$ of distilled water using a blender (Maspion, Indonesia). The extract was then added to a cuvette and its absorbance was measured with a spectrophotometer (Shimadzu, Japan). The chlorophyll content was calculated using the formulae.

Chlorophyll $a=1.07$ (OD663) -0.094 (OD644)

Chlorophyll $b=1.77$ (OD644) -0.28 (OD663)

\subsection{Protein content}

The protein content was determined by the MicroKjeldahl method (AOAC, 2007). A $0.2 \mathrm{~g}$ sample was placed in a $30 \mathrm{~mL}$ Kjeldahl flask, then $2 \mathrm{~g}$ of $\mathrm{K}_{2} \mathrm{SO}_{4}$,
$50 \mathrm{mg} \mathrm{HgO}$, and $2.5 \mathrm{~mL} \mathrm{H}_{2} \mathrm{SO}_{4}$ were added. The protein content was calculated using the formulae.

$$
\begin{aligned}
& \% N=[(m l ~ H C l-m l \text { blank }) / m g \text { sample }] \times 100 \% \\
& \% \text { Protein }(\% w w)=\% N \times 6.25 \text { (protein factor })
\end{aligned}
$$

\subsection{Tensile strength}

A tensile strength analysis was performed according to the methods by Huh et al. (2019). The samples were cooked for 2 mins at $100^{\circ} \mathrm{C}$. They were then cut into a string $(10 \mathrm{~cm})$ and attached to the sample holder TAXT2i texture analyser (Universal Testing Machine, Brookfield, USA), set to TRAC mode with a tensile speed of $19.9 \mathrm{~mm} / \mathrm{s}$. This test was repeated three times for each treatment and the averages were taken. The tensile strength was measured with the formula.

$T S=F / A=k g f / \mathrm{cm}^{2}=M P a=1,000 \mathrm{kPa}$

Where TS is tensile strength $\left(\mathrm{kgf} / \mathrm{cm}^{2}\right), \mathrm{F}$ is tensile load $(\mathrm{N})$, and $\mathrm{A}$ is the cross-sectional area $\left(\mathrm{cm}^{2}\right)$.

\subsection{Sensory analysis}

The sensory analysis was performed following Anggraeni and Saputra (2018) on 30 panellists using five scales to determine their level of preference based on colour, texture, aroma, and flavour. The preference test consisted of values: 1 - dislike, 2 - somewhat dislike, 3 neutral, 4 - somewhat like, and 5 - like.

\section{Results and discussion}

\subsection{Colour $(L, a, b)$}

The result of $\mathrm{L}^{*}, \mathrm{a}^{*}$, and $\mathrm{b}^{*}$ colour assays using a chromameter on raw noodles with $C$. racemosa extracts are presented in Table 1. The $\mathrm{L}$ parameter indicates the level of brightness on a scale of 0 (dark/black) to 100 (bright) (Deskawi et al., 2015). Our brightness measurements ranged from 47.52 to 66.70 with the lowest value of 47.52 found in the $75 \%$ C. racemosa noodles, and the highest value of 66.70 found in the control sample. Sanjaya et al. (2016) mentioned that L* values below 50 tend to be considered dark. The brightness (L) results indicated that the addition of $C$. racemosa extract significantly affects the brightness of the noodles. Noodles treated with $C$. racemosa were darker than the control. As the concentration increased, the brightness level decreased because of the green colour the $C$. racemosa extract gave the noodles.

The highest $\mathrm{a}^{*}$ value of 17.79 was found in the $75 \%$ C. racemosa extract, and the lowest value of 0.72 was found in the control noodles. The higher the concentration, the greener the colour. A high a* value indicates the accumulation of chlorophyll from $C$. 
Table 1. Colour assay of noodle

\begin{tabular}{ccccc}
\hline \multirow{2}{*}{ Treatment } & \multicolumn{3}{c}{ Colour } & $\begin{array}{c}\text { Degrees Hue } \\
\text { ('Hue) }\end{array}$ \\
\cline { 2 - 4 } Control & $66.70 \pm 0.85^{\mathrm{a}}$ & $0.72 \pm 0.07^{\mathrm{a}}$ & $18.10 \pm 0.17^{\mathrm{a}}$ & $87.71 \pm 0.20^{\mathrm{a}}$ \\
A & $60.86 \pm 1.32^{\mathrm{b}}$ & $-6.65 \pm 0.19^{\mathrm{b}}$ & $19.84 \pm 0.18^{\mathrm{b}}$ & $71.31 \pm 0.58^{\mathrm{b}}$ \\
B & $55.08 \pm 1.37^{\mathrm{c}}$ & $-14.89 \pm 0.20^{\mathrm{c}}$ & $15.20 \pm 0.19^{\mathrm{c}}$ & $45.56 \pm 0.66^{\mathrm{c}}$ \\
C & $47.52 \pm 1.24^{\mathrm{d}}$ & $-17.79 \pm 0.27^{\mathrm{d}}$ & $12.87 \pm 0.23^{\mathrm{d}}$ & $36.56 \pm 1.61^{\mathrm{d}}$ \\
\hline
\end{tabular}

Values are presented as mean \pm standard deviation. Values with different superscript in the same column are significant different $(\mathrm{P}<0.05)$. Control: Raw noodle without $C$. racemosa extract, A: Raw noodle with $25 \%$. racemosa extract, B: Raw noodle with $50 \%$ C. racemosa extract, and C: Raw noodle with $75 \%$ C. racemosa extract.

racemosa. According to Merdekawati and Susanto (2009), Caulerpa sp. contain chlorophyll derivatives (18.731\%), chlorophyll-a (26.817\%), and chlorophyll-b $(12.906 \%)$. A low a* value is inversely proportional to $\mathrm{L}^{*}$, which means that the greener the product, the darker the colour. Putri et al. (2012), extracted chlorophyll from suji leaves and found that the higher the chlorophyll concentration, the darker the colour.

The $b^{*}$ value results showed that the noodles with a $25 \%$ extract were more yellow than the other samples. This is because of the carotenoid pigments derived from C. racemosa, which contain chlorophyll-a, chlorophyllb, beta carotene, and caulerpin (Paul et al., 2013; Sihono et al., 2018). According to Hasbullah et al. (2014), the carotenoid content in C. racemosa is $0.0013 \mathrm{mg} / \mathrm{kg}$, and Supriadi et al. (2016) emphasized that it contains $0.013 \mathrm{mg} / \mathrm{kg}$ carotenoid pigments. Furthermore, Agusman et al. (2020) confirmed that Caulerpa sp. extract may increase the $a^{*}(-)$ and $b^{*}(+)$ values that affect the incline of green and yellow colour intensity in noodles because of the chlorophyll and carotenoid it contains (Gaillande et al., 2017; Sihono et al., 2018).

\subsection{Tensile strength}

The tensile strength of noodles is influenced by gluten and amylose from flour. Gluten plays a role in forming elasticity, while amylose is forming the strength when the noodles are tensed. Tensile strength is also influenced by salt. Salt helps form the dough and inclines gluten texture to produce high stability and tensile strength. However, a high salt content could be harmful to the dough texture as excessive salt ions will ruin the gluten tissue (Hu et al., 2017).

Table 2 shows the varied tensile strength of the raw and cooked noodles. The tensile strength of raw noodles ranged between $15.1-17.5 \mathrm{kPa}$, whereas the tensile strength of cooked noodles ranged between 55.4$58.1 \mathrm{kPa}$. Wheat flour in this study contained amylopectin, which provided tensile strength. The difference in tensile strength between raw and cooked noodles comes from the breakdown of amylopectin in starch. When starch heats up, some amylopectin double helix fractions are stretched and are released when a hydrogen bond is broken. The high temperatures resulted in more hydrogen being broken, resulting in water being absorbed in starch granules and forming a stronger bond (Li et al., 2017).

Table 2. Tensile strength of noodle

\begin{tabular}{ccc}
\hline \multirow{2}{*}{ Sample } & \multicolumn{2}{c}{ Tensile Strength Value $(\mathrm{kPa})$} \\
\cline { 2 - 3 } & Raw Noodles & Cooked Noodles \\
\hline Control & $16.9 \pm 0.28^{\mathrm{a}}$ & $55.4 \pm 2.12^{\mathrm{a}}$ \\
$\mathrm{A}$ & $17.5 \pm 0.78^{\mathrm{a}}$ & $57.9 \pm 1.51^{\mathrm{a}}$ \\
$\mathrm{B}$ & $15.1 \pm 1.41^{\mathrm{a}}$ & $55.4 \pm 0.94^{\mathrm{a}}$ \\
$\mathrm{C}$ & $15.6 \pm 1.58^{\mathrm{a}}$ & $58.1 \pm 1.12^{\mathrm{a}}$ \\
\hline
\end{tabular}

Values are presented as mean \pm standard deviation. Values with different superscript in the same column are significant different $(\mathrm{P}<0.05)$. Control: Raw noodle without $C$. racemosa extract, A: Raw noodle with $25 \%$ C. racemosa extract, B: Raw noodle with $50 \%$ C. racemosa extract, and C: Raw noodle with $75 \%$ C. racemosa extract.

The tensile strength in the noodles in this study was lower than reported by Kurniasari et al. (2015) who did a similar study on tapioca flour. The tensile strength of noodles without tapioca flour is $190 \mathrm{kPa}$ because wheat flour contains less (89.77\%) amylopectin than tapioca flour (91.94\%) (Imanningsih, 2012). However, this study's noodle tensile strength was higher than Nurcahyo et al. (2014), which ranged from 1.87 to $2.58 \mathrm{kPa}$ because of the use of breadfruit flour, which causes a decrease in the availability of gluten protein, thus reducing tensile strength.

Noodles with added C. racemosa extract showed no significantly different tensile strength. A high amylose results in a compact and robust texture (Herawati et al., 2017; Huh et al., 2019). Moreover, tensile strength is also influenced by salt content. Salt helps to form the dough and incline gluten texture to produce high stability and tensile strength. However, higher salt content could be harmful to the dough texture as the excessive salt ion will ruin the gluten tissue (Hu et al., 2017). A different result was obtained by Agusman et al. (2020), where the Caulerpa sp. extract can increase the tensile strength. The higher salt content on Caulerpa sp. could affect the texture. The various salt content on Caulerpa sp. might 
cause by the dynamic of salinity in its habitat (Guo et al., 2015).

\subsection{Protein content}

The protein content measurement results (Figure 1) of noodles after $C$. racemosa extract addition ranged from 6.20 to $10.18 \%(\mathrm{dw})$. The highest content was found in noodles with $75 \%$ C. racemosa extract and the lowest was in the control noodles. As the results reflect, protein in noodles comes directly from the protein-rich C. racemosa extract. Bhuiyan et al. (2016) explained that C. racemosa contains $19.72 \%$ protein, which is supported by the similar findings of Nagappan and Vairappan (2014) of $17.36 \%$.

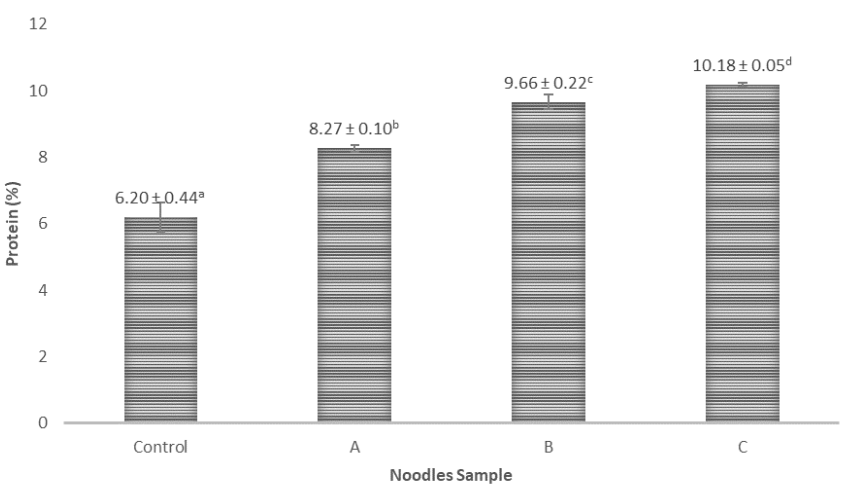

Figure 1. Protein of noodle. Values are presented as mean \pm standard deviation. Values with different superscript in the same column are significant different $(\mathrm{P}<0.05)$. Control: Raw noodle without $C$. racemosa extract, A: Raw noodle with $25 \% C$. racemosa extract, B: Raw noodle with $50 \% C$. racemosa extract, and C: Raw noodle with $75 \%$ C. racemosa extract.

Alkaloid compounds are indicative of the presence of alkaline groups. C. racemosa contains alkaloid compounds, as is indicated by protein element nitrogen $(\mathrm{N}$ ), as well as triterpenoids and tannins (Kurniasari et al., 2015). The composition of chemical elements in proteins is carbon $(\mathrm{C}) 50 \%$, hydrogen $(\mathrm{H}) 75 \%$, oxygen (O) 23\%, and nitrogen (N) 16\% (Raj et al., 2015). The noodles without $C$. racemosa extract (control) and noodles with $25 \% C$. racemosa extract had a protein content of $6.20 \%$ and $8.27 \%$ respectively, falling short of the $9 \%$ minimum stipulated by the National Standard of Indonesia (SNI) No. 2987-2015. However, the noodles with $50 \%$ and $75 \%$ C. racemosa extract did meet the requirements with $9.66 \%$ and $10.18 \%$ protein content respectively. These results concur with the findings of Kumar et al. (2017) who did a similar study on biscuits and found that the $C$. racemosa extract concentration is proportional to the protein content.

\subsection{Total phenol}

The total phenol assay aimed to determine the total phenolic compounds in the samples. Based on Figure 2, the total phenol ranged between 178.65-392.56 ppm, with the highest value was the noodles with the $75 \%$ extract of $392.56 \mathrm{ppm}$, and the lowest value was the control sample of $178.65 \mathrm{ppm}$. The higher the amount of extract added, the higher the total phenol value. It is related to the total phenol content on C. racemosa. According to Yap et al. (2019), C. racemosa contains between 10.33 and $13.41 \mathrm{mg} \mathrm{GAE} / \mathrm{g}$ phenol. According to Nurjanah et al. (2019a), the total phenol in $C$. racemosa is $28.56 \mathrm{mg} \mathrm{GAE} / \mathrm{g}$ and is influenced by external factors such as habitat, the availability of sunlight, and harvest time. This study had a linear relationship between the phenolic compounds and the sample's antioxidant activity. As shown in Figure 3, the total phenol ranged between 178.65 and $392.56 \mathrm{ppm}$, with the highest phenol value of $392.56 \mathrm{ppm}$ measured from the noodles with the $75 \%$ extract, and the lowest value of $178.65 \mathrm{ppm}$ from the control sample. The higher the extract concentration that was added, the higher the total phenol value. These results correspond to Kumar et al. (2017), who found that the total phenol content in biscuits increased parallel with the addition of $C$. racemosa concentration.

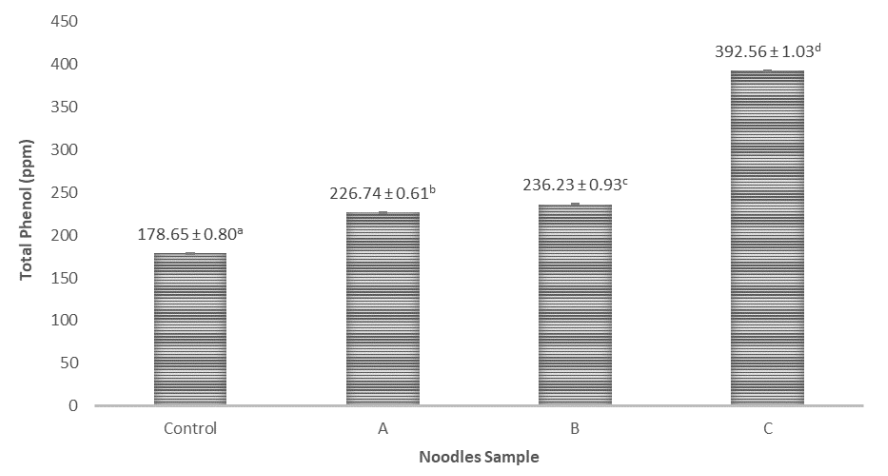

Figure 2. Total phenol of noodle. Values are presented as mean \pm standard deviation. Values with different superscript in the same column are significant different $(\mathrm{P}<0.05)$. Control: Raw noodle without $C$. racemosa extract, A: Raw noodle with $25 \%$ C. racemosa extract, B: Raw noodle with $50 \% C$. racemosa extract, and C: Raw noodle with $75 \%$ C. racemosa extract

\subsection{Chlorophyll}

Caulerpa racemosa naturally contains chlorophyll-a and b (Tapotubun et al., 2020) and chlorophyll-a is less polar and blue-green, while chlorophyll-b is polar and yellow-green (Indrasti et al., 2018). The total chlorophyll assay aimed to determine the total chlorophyll-a and $b$ content of the noodles (Figure 3). The chlorophyll contents ranged from 8.31 to $9.49 \mathrm{~g} / \mathrm{mL}$, with the highest value of $9.49 \mathrm{~g} / \mathrm{mL}$ in noodles with the $75 \%$ C. racemosa extract, followed by the $8.89 \mathrm{~g} / \mathrm{mL}$ from the $50 \% C$. racemosa extract, and the lowest value of $8.31 \mathrm{~g} / \mathrm{mL}$ in the noodles with the $25 \%$ C. racemosa extract.

The total chlorophyll content of the noodles was 
linearly proportional to the concentration of the $C$. racemosa extract. The higher the concentration extract, the higher the chlorophyll-a and chlorophyll-b content of the noodle. There tended to be more chlorophyll-b in noodles than chlorophyll-a. However, according to Sarojini et al. (2015), C. racemosa contains chlorophylla $10.08 \times 10^{-6}-17.4 \times 10^{-6} \mathrm{~g} / \mathrm{mL}$ and chlorophyll-b $15.2 \times 10^{-6}-31.2 \times 10^{-6} \mathrm{~g} / \mathrm{mL}$. The chlorophyll contents in this study were higher, which increased in line with the green colour intensity $\left(\mathrm{a}^{*}\right)$ from the colour analysis.

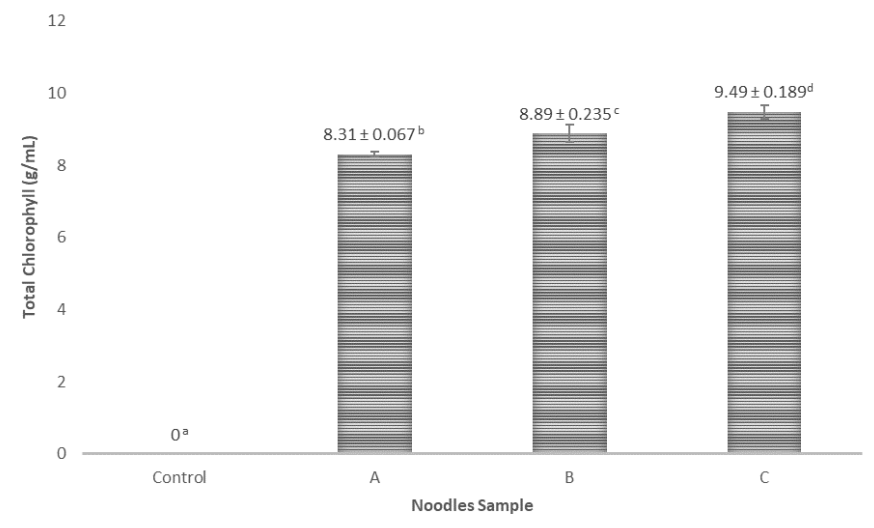

Figure 3. Total chlorophyll of noodle. Values are presented as mean \pm standard deviation. Values with different superscript in the same column are significant different $(\mathrm{P}<0.05)$. Control: Raw noodle without $C$. racemosa extract, A: Raw noodle with $25 \% C$. racemosa extract, B: Raw noodle with $50 \% C$. racemosa extract, and C: Raw noodle with $75 \%$ C. racemosa extract.

\subsection{Sensory}

\subsubsection{Appearance}

The panellists' preferences are presented in Table 3. The noodles in this study were identical in shape and size. The only visible difference was the green colour intensity (Figure 4). The appearance test results for noodles with $50 \%$ C. racemosa extract were significantly different from the $75 \%$ C. racemosa. All noodles have a dominant green colour, but none were greener than the $75 \%$ C. racemosa extract. The noodles with $50 \% C$. racemosa extract were the most preferred by panellists. Noodles with $25 \%$ C. racemosa extract and the control noodles were less preferred for their appearance and colour. There was no green colour in the control noodles because there were no additions of $C$. racemosa extract. The higher addition of concentration of C. racemosa extract, the greener the appearance, and the more it was preferred by the panelists. The study on green extract $C$. racemosa addition was accorded to Shere et al. (2018), the higher the addition of spinach puree, the colour of the buns are dark green. The formation of green colour is the colour of chlorophyll pigments derived from spinach. On the other hand, Kumar et al. (2017) found that the consumer less preferred biscuits with a higher concentration of $C$. racemosa. It is caused by the decreasing colour intensity on $\mathrm{L}, \mathrm{a}^{*}$ dan $\mathrm{b}^{*}$.

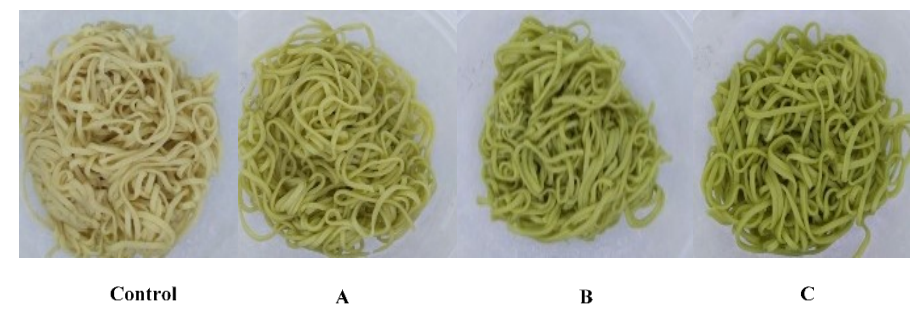

Figure 4. The colour of noodles with the different concentration of $C$. racemosa extract. Control: Raw noodle without $C$. racemosa extract, A: Raw noodle with $25 \% C$. racemosa extract, B: Raw noodle with $50 \%$ C. racemosa extract, and C: Raw noodle with $75 \%$ C. racemosa extract.

\subsubsection{Aroma}

The aroma was one of the sensory parameters, relying on the sense of smell (Table 3). The most preferred aroma was from the noodles with $75 \% C$. racemosa extract, with a score of 4.23 . However, the score of 4.13 for noodles with $50 \%$ C. racemosa extract came very close. Both noodles were well-liked by the panellists because both noodles had a distinctive, slightly fishy, aroma because of the C. racemosa. The aroma of C. racemosa is specific to seaweed and the fishy smell comes from the amino acid (Puspita et al., 2019). Moreover, Vitriasari and Suyanto (2012) found that the addition of seaweed greatly affects a product's aroma because, during the processing, many components such as glutinous rice flour are mixed. The aroma in food is determined by one component and specific components that give a distinctive odour and the ratio of various ingredients used. The addition of C. racemosa extract to the $25 \%$ noodles appeared to have an indistinguishable aroma from the control noodles. However, there was a difference in the aroma that came from the control

Table 3. Sensory of noodles

\begin{tabular}{ccccc}
\hline Sample & Appearance & Aroma & Taste & Texture \\
\hline Control & $2.40 \pm 1.04^{\mathrm{a}}$ & $2.37 \pm 1.22^{\mathrm{a}}$ & $2.43 \pm 1.01^{\mathrm{a}}$ & $2.80 \pm 0.91^{\mathrm{a}}$ \\
A & $2.91 \pm 0.67^{\mathrm{b}}$ & $3.50 \pm 1.04^{\mathrm{b}}$ & $3.10 \pm 0.88^{\mathrm{b}}$ & $3.47 \pm 0.85^{\mathrm{b}}$ \\
B & $3.77 \pm 0.63^{\mathrm{c}}$ & $4.13 \pm 0.90^{\mathrm{c}}$ & $4.07 \pm 0.83^{\mathrm{c}}$ & $4.03 \pm 0.87^{\mathrm{c}}$ \\
C & $4.60 \pm 0.56^{\mathrm{d}}$ & $4.23 \pm 0.94^{\mathrm{d}}$ & $4.43 \pm 0.77^{\mathrm{d}}$ & $4.27 \pm 0.96^{\mathrm{c}}$ \\
\hline
\end{tabular}

Values are presented as mean \pm standard deviation. Values with different superscript in the same column are significant different $(\mathrm{P}<0.05)$. Control: Raw noodle without $C$. racemosa extract, A: Raw noodle with $25 \%$. racemosa extract, B: Raw noodle with $50 \%$ C. racemosa extract, and C: Raw noodle with $75 \%$ C. racemosa extract. 
noodles' dough.

\subsubsection{Taste}

Taste or flavour, is an assessment of food products that combine with the smell. The panellists reported sweet, bitter, sour, and salty tastes (Table 3 ). The mostliked noodles by the panellist were those with $75 \% C$. racemosa extract. They had a salty taste thanks to the $C$. racemosa extract coming from a highly saline environment. In contrast, the control noodles were tasteless. Furthermore, C. racemosa noodles have a savoury taste that comes from amino acid derivatives, such as alanine, glutamic, and glycine (Ma'ruf et al., 2013). Puspita et al. (2019) explained that cream soup with $C$. racemosa had a savoury taste, while other food additives did not have a significant effect.

\subsubsection{Texture}

The texture is a pressure sensation that is experienced when biting, chewing, swallowing, or touching the product. Ingredients influence the texture of a product (Table 3 ). The most preferred texture was of the noodles with $75 \%$ C. racemosa extract added, with an average score of 4.27 , followed by the $50 \%$ noodles with 4.03 points. The $25 \%$ C. racemosa extract scored 3.47 , and the lowest score of 2.8 was for the control noodle. The panellists indicated that they preferred the higher concentrations and a slightly chewy texture. The noodle elasticity or chewiness comes from gluten and amylopectin contained in the flour. Gluten plays a role in coagulation and starch gelatinization during heating, while amylopectin works like glue for the tissue and strength of the noodle structure (Nurjanah et al., 2019b). This study's chewiness further influences by the salt contained in $C$. racemosa, as it strengthens the dough texture. C. racemosa is low in fibre, so it did not affect the noodles' hardness (Agusman et al., 2020).

\section{Conclusion}

The addition of $C$. racemosa extracts affected the characteristics of noodles. The higher the concentration, the greener the colour intensity, and the phenol and chlorophyll content. While the addition of C. racemosa did not affect the tensile strength, it did positively influence consumer preference.

\section{Conflict of interest}

The authors have no conflicts of interest to declare.

\section{Acknowledgment}

This study was funded by the Ministry of Research, Technology and Higher Education, Indonesian Republic, with Grant No. 257-105/UN7.P4.3/PP/2019.

\section{References}

Adejuwon, O.H., Jideani, A.I.O. and Falade, K.O. (2019). Quality and public health concerns of instant noodles as influenced by raw materials and processing technology. Food Reviews International, 36(3), 1-42. https:// doi.org/10.1080/87559129.2019.1642348

Agusman, Murdinah. and Wahyuni, T. (2020). The nutritional quality and preference of wheat noodles incorporated with Caulerpa sp. seaweed. International Food Research Journal, 27(3), 445453.

Anggraeni, R. and Saputra, D. (2018). Physicochemical characteristics and sensorial properties of dry noodle supplemented with unripe banana flour. Food Research, 2(3), 270-278. https://doi.org/10.26656/ fr.2017.2(3).061

AOAC. (2005). Official Methods of Analysis. Washington, D.C., USA: Association of Official Analytical Chemists.

Bhuiyan, M.K.A., Qureshi, S., Kamal, A.H., Mustafa., Uddin, S.A. and Siddique, M.A.M. (2016). Proximate chemical composition of sea grapes Caulerpa racemosa (J. Agardh, 1873) collected from a sub-rropical Coast. Virology and Mycology, 5(2), 1000158 https://doi.org/10.4172/21610517.1000158

FAO. (2017). Fast Green FCF. In Monograph by FAO/ WHO Committee on Food Additives 84th, p. 0-6. Rome, Italy: FAO.

Gaillande, C., Payri, C., Remoissenet, G. and Zubia, M. (2017). Caulerpa consumption, nutritional value and farming in the Indo-Pacific region. Journal of Applied Phycology, 29(5), 2249-2266. https:// doi.org/10.1007/s10811-016-0912-6

Guo, H., Yao, J., Sun, Z. and Duan, D. (2015). Effects of salinity and nutrients on the growth and chlorophyll fluorescence of Caulerpa lentillifera. Chinese Journal of Oceanology and Limnology, 33(2), 410418. https://doi.org/10.1007/s00343-015-4105-y

Hasbullah, D., Akmal, Bahri, S., Agung, I., Suaib, M. and Ilham. (2014). Implementation of various basic substrate as a media for Lawi Lawi Caulerpa $s p$. production. Octopus, 3(1), 244-251.

Hendriyani, I. and Setiari, N. (2009). Chlorophyll content and growth of string beans (Vigna sinensis) at different water supply levels. Jurnal Sains and Matematika, 17(3), 145-150. 
Hruškqvá, M., Švec, I. and Sekerqvá, H. (2011). Colour analysis and discrimination of laboratory prepared pasta by means of spectroscopic methods. Czech Journal of Food Science, 29(4), 346-353. https:// doi.org/10.17221/25/2011-CJFS

Hu, Y., Wei, J. and Chen, Y. (2017). The impact of salt on the quality of fresh wheat noodle. Acta Universitatis Cibiniensis Series E: Food Technology, 21(2), 53-61. https://doi.org/10.1515/aucft-20170015

Huh, H.J., Shin, W.K. and Kim, Y. (2019). Textural and cooking qualities of noodles made with soy flour and hydroxypropyl methylcellulose. International Food Research Journal, 26(2), 421-428.

Imanningsih, N. (2012). Gelatinisation profile of several flour formulations for estimating cooking behaviour. Penel Gizi Makan, 35(1), 13-22.

Indrasti, D., Andarwulan, N., Purnomo, E.H. and Wulandari, N.U.R. (2018). Stability of chlorophyll as natural colorant: A review for suji (Dracaena angustifolia (medik.) roxb.) leaves' case. Current Research in Nutrition and Food Science, 6(3), 609625. https://doi.org/10.12944/CRNFSJ.6.3.04

Koswara, S. (2009). Noodles Processing technology. Retrieved on December 14, 2019 from http:// tekpan.unimus.ac.id/wp-content/uploads/2013/07/ Teknologi-Pengolahan-Mie-teori-dan-praktek.pdf

Kumar, A., Krishnamoorthy, E., Devi, H.M., Uchoi, D., Tejpal, C.S., Ninan, G. and Zynudheen, A.A. (2017). Influence of sea grapes (Caulerpa racemosa) supplementation on physical, functional. and antioxidant properties of semi-sweet biscuits. Journal of Applied Phycology, 30(2), 1393-1403. https:// doi.org/10.1007/s10811-017-1310-4

Kurniasari, E., Waluyo, S. and Sugianti, C. (2015). The study of drying rate and physical characteristics of dried noodles with mixed tapioca and wheat flour. Jurnal Teknik Pertanian Lampung, 4(1), 1-8.

Li, M., Dhital, S. and Wei, Y. (2017). Multilevel structure of wheat starch and its relationship to noodle eating qualities. Comprehensive Reviews in Food Science and Food Safety, 16(5), 1042-1055. https://doi.org/10.1111/1541-4337.12272

Ma'ruf, W.F.M., Ibrahim, R., Dewi, E.N., Susanto, E. and Amalia, U. (2013). Profil rumput laut Caulerpa racemosa dan Gracilaria verrucosa sebagai edible food. Saintek Perikanan: Indonesian Journal of Fisheries Science and Technology, 9(1), 68-74. https://doi.org/10.14710/ijfst.9.1.68-74 [In Bahasa Indonesia].

Merdekawati, W. and Susanto, A.B. (2009). Content, composition. and health potential of seaweed pigment. Squalene, 4(2), 41-47. https:// doi.org/10.15578/squalen.v4i2.147

Minarovičová, L., Lauková, M., Kohajdova, Z., Karovicova, J., Dobrovicka, D. and Kuchtova, V. (2018). Qualitative properties of pasta enriched with celery root and sugar beet by-products. Czech Journal of Food Sciences, 36(1), 66-72. https:// doi.org/10.17221/242/2017-CJFS

Nagappan, T. and Vairappan, C.S. (2014). Nutritional and bioactive properties of three edible species of green algae, genus caulerpa (Caulerpaceae). Journal of Applied Phycology, 26(2), 1019-1027. https:// doi.org/10.1007/s10811-013-0147-8

Nurcahyo, E., Amanto, B.S. and Nurhartadi, E. (2014). Study on the use of breadfruit flour (Artocarpus communis) as flour substitution in the dry noodle making. Jurnal Teknosains Pangan, 3(2), 57-65.

Nurjanah, N., Jacoeb, A.M., Asmara, D.A. and Hidayat, T. (2019a). Phenol component of fresh and boiled sea grapes (Caulerpa sp.) from Tual, Maluku. Food ScienTech Journal, 1(1), 31-39. https:// doi.org/10.33512/fsj.v1i1.6244

Nurjanah, H., Lestari, W. and Manggabarani, S. (2019b). Formulation of mocaf mie with natural colors from purples sweet potatoes. Jurnal Dunia Gizi, 2(2), 108 -115. https://doi.org/10.33085/jdg.v2i2.4588

Okafor, S.N., Obonga, W. and Ezeokonkwo, M.A. (2016). Assessment of the health implications of synthetic and natural food colourants - a critical review. UK Journal of Pharmaceutical Biosciences, 4(4), 1-11. https://doi.org/10.20510/ukjpb/4/ i4/110639

Oktiarni, D., Ratnawati, D. and Anggraini, D.Z. (2012). Utilization of red dragon fruit peel (Hylocereus polyrhizus sp.) as colorant and natural preservative of wet noodle. Jurnal Gradien, 8(2), 819-824.

Paul, N.A., Neveux, N., Magnusson, M. and de Nys, R. (2013). Comparative production and nutritional value of "sea grapes" - the tropical green seaweeds C. lentillifera and C. racemosa. Journal of Applied Phycology, 26(4), 1833-1844. https:// doi.org/10.1007/s10811-013-0227-9

Priyadarisani, D., Sundar, B.B. and Rajkiran, J. (2014). Determination of total phenolic content, antioxidant capacity and radical scavenging capacity of vegetable biomass. International Journal of Engineering and Technical Research, 2(4), 304-308.

Puspita, D., Merdekawati, W. and Rahangmetan, N.S. (2019). Utilization of Caulerpa racemosa in the production of instant cream soup. Jurnal Teknologi Industri Pertanian, 29(1), 72-78. https:// doi.org/10.24961/j.tek.ind.pert.2019.29.1.72 
Putri, W.D.R., Zubaidah, E. and Sholahudin, N. (2012). Extraction of suji leaves natural colorant, study on the effects of blanching and types of extracting materials. Jurnal Terknologi Pertanian, 4(1), 13-24.

Raj, A., Mala, K. and Prakasam, A. (2015). Phytochemical analysis of marine macroalgae Caulerpa racemosa (J. Agardh) (Chlorophyta Caulerpales) from Tirunelveli District, Tamilnadu, India. Journal of Global Biosciences, 4(8), 30553067.

Sadar, P., Dande, P., Kulkarni, N. and Pachori, R. (2017). Evaluation of toxicity of synthetic food colors on human normal flora and yeast. International Journal of Health Sciences and Research, 7(8), 110-114. https://doi.org/10.13140/ RG.2.2.16583.60322

Saleem, N., Nasreen Umar, Z. and Ismat khan, S. (2013). Survey on the use of synthetic food colors in food samples procured from different educational institutes of Karachi city. Journal of Tropical Life Science, 3(1), 1-7. https://doi.org/10.11594/ jtls.03.01.01

Sanjaya, Y.D., Sumardianto. and Riyadi, P.H. (2016). The effect of roselle (Hibiscus sabdariffa Linn.) extract addition to color and quality of shrimp (Acetes sp.) Paste. Jurnal Pengolahan Dan Bioteknologi Hasil Perikanan, 5(2), 1-9.

Sarojini, Y., Neelima, P. and Sujata, B. (2015). The seasonal variations in distribution of photosynthetic pigments in two species of Phaeophyceae and the effect of light, dissolved oxygen and nutrients on their distribution. Annals of Biological Research, 6 (3), 36-40.

Shere, P.D., Devkatte, A.N. and Pawar, V.N. (2018). Studies on production of functional noodles with incorporation of spinach puree. International Journal of Current Microbiology and Applied Sciences, 7(6), 1618-1628. https://doi.org/10.20546/ ijcmas.2018.706.193

Sihono, S., Tarman, K., Madduppa, H. and Januar, H.I. (2018). Metabolite profiles and antioxidant activity of Caulerpa racemosa with different handlings. Squalen Bulletin of Marine and Fisheries Postharvest and Biotechnology, 13(3), 93-100. https://doi.org/10.15578/squalen.v13i3.355

Sikander, M., Malik, A., Khan, M.S.G., Ul-ain, Q. and Khan, R.G. (2017). Instant noodles: are they really good for health? A review. Electronic Journal of Biology, 13(3), 222-227.

Supriadi, Syamsuddin, R., Abustang and Yasir, I. (2016). The growth and carotenoid content of Lawi Lawi Caulerpa racemosa grown in different substrates.
Jurnal Rumput Laut Indonesia, 1(2), 117-122.

Tapotubun, A.M., Matrutty, T.E.A.A., Riry, J., Tapotubun, E.J., Fransina, E.G., Mailoa, M.N., Riry, W.A., Setha, B. and Rieuwpassa, F. (2020). Seaweed Caulerpa sp position as functional food. IOP Conference Series: Earth and Environmental Science, 517(1), 1-8. https://doi.org/10.1088/1755$1315 / 517 / 1 / 012021$

Vitriasari, E. and Suyanto, A. (2012). The characteristics of 'dodol' purple sweet potato (Ipomea batatas blackie) with addded of seaweed flour. Jurnal Pangan Dan Gizi, 3(6), 29-36. https:// doi.org/10.26714/jpg.3.1.2012.

Yadav, D.N., Sharma, M., Chikara, N., Anand, T. and Bansal, S. (2014). Quality characteristics of vegetable-blended wheat-pearl millet composite pasta. Agricultural Research, 3(3), 263-270. https:// doi.org/10.1007/s40003-014-0117-7

Yap, W.F., Tay, V., Tan, S.H., Yow, Y.Y. and Chew, J. (2019). Decoding antioxidant and antibacterial potentials of Malaysian green seaweeds: Caulerpa racemosa and Caulerpa lentillifera. Antibiotics, 8(3), 152. https://doi.org/10.3390/antibiotics 8030152 